\title{
EFEKTIFITAS PERMAINAN TRADISONAL CAK BUR TERHADAP PENINGKATAN INTERAKSI SOSIAL SISWA TAMAN KANAK-KANAK
}

\author{
Prima Aulia \\ Fakultas Ilmu Pendidikan, Universitas Negeri Padang, Indonesia \\ Email : Primaaulia.psi@gmail.com
}

\begin{abstract}
ABSTRAK
Penelitian ini bertujuan untuk mengetahui efektifitas permainan cak bur terhadap peningkatan interaksi sosial siswa taman kanak-kanak di kota Padang. Penelitian ini melibatkan 37 orang siswa sebagai subjek penelitian, dimana 18 orang masuk dalam kelompok eksperimen dan 19 orang lainnya masuk dalam kelompok kontrol, pemilihan subjek penelitian dan penempatannya kedalam kelompok eksperimen dan kontrol dilakukan secara acak. Desain penelitian ini adalah pretest postest group control. Pengumpulan data menggunakan skala interaksi sosial, untuk menguji kualitas alat ukur digunakan uji validitas isi dengan profesional judgement sedangkan untuk melihat reliabilitas menggunakan bantuan SPSS 16.0 for windows dengan teknik Alpha Cronbach. Skala interaksi social terdiri dari 57 aitem dengan koefisien alpha sebesar $(\alpha)$ 0,979. Pengujian hipotesis menggunakan teknik statistik T-test dengan bantuan SPSS 16.0 for Windows yang menunjukan taraf signifikansi sebesar 0,000. Hal ini menunjukan bahwa permainan cak bur terhadap peningkatan interaksi sosial siswa taman kanak-kanak.
\end{abstract}

Kata Kunci: permainan cak bur, interaksi sosial

\begin{abstract}
This study aims to determine the effectiveness of cak bur games to increase kindergarten students social interaction in the city of Padang. This study involved 37 students as research subjects, 18 student were included in the experimental group and 19 others were included in the control group, the selection of research subjects and their placement into the experimental and control groups was done randomly. The design of this study was the pretest posttest group control. Data collection uses a scale of social interaction, to test the quality of instruments used content validity test with professional judgment while to see reliability using SPSS 16.0 for windows with Alpha Cronbach technique. The social interaction scale consists of 57 items with an alpha coefficient of $(\alpha)$ 0.979. Hypothesis testing usesl techniques T-test with the help of SPSS 16.0 for Windows. a significance level of 0,000. This shows that the cak bur game is the effectiveness games to increasing the social interaction of kindergarten students.
\end{abstract}

Keyword : cak bur game, social interaction

\section{PENDAHULUAN}

Dunia anak adalah dunia

bermain, melalui bermain anak memperoleh pelajaran yang mengandung aspek perkembangan kognitif, sosial, emosi, dan fisik. Melalui kegiatan bermain dengan berbagai macam bentuk permainan, anak diransang untuk mampu berkembang secara umum, baik perkembangan berfikir, emosi, dan sosial (Kementrian Pendidikan dan Kebudayaan dalam Latief, 2013).

Secara Bahasa bermain diartikan sebagai suatu aktifitas yang lansung atau spontan, dimana seorang anak berinteraksi dengan orang lain, bendabenda disekitarnya, dilakukan dengan senang (gembira) atas inisiatif sendiri, menggunakan daya khayal (imajinatif), 
menggunakan panca indra, dan seluruh anggota tubuhnya. Menurut Brooks dan Elliot (dalam Retno dan Wismiarti, 2010) bermain merupakan istilah yang digunakan secara bebas sehingga arti utamanya mungkin hilang. Arti yang lebih tepat adalah setiap kegiatan yang dilakukan untuk timbulnya kesenangan tanpa menimbulkan hasil akhir. Bermain dilakukan secara sukarela dan tidak ada paksaan atau tekanan dari luar kewajiban.

Pada dasarnya anak-anak selalu termotivasi untuk bermain. Artinya bermain secara alamiah memberi kepuasan pada anak, melalui bermain bersama dalam kelompok atau sendiri tanpa orang lain, anak mengalami kesenangan sehingga memberikan kepuasan bagi anak (Montolalu dkk dalam Latif, 2013). Namun kemajuan teknologi yang semakin pesat membuat perubahan pada pola permainan anak. Sekarang anak-anak lebih suka bermain permainan digital seperti video game, dan game online. Permainan ini dikenal dengan permainan modern karena menggunakan peralatan yang canggih dan muktahir yang sangat berbeda dengan permainan tradisional (Nur, 2013). Menurut Suyami (dalam Wahyuni 2009) sifat permainan modern adalah personal, yaitu anak bermain sendiri, tidak berinteraksi sosial dan tidak terlibat secara emosional dengan teman-temannya, sehingga perkembangan jiwa anak tidak bisa mengerti perasaan orang lain dan tidak mampu dengan teman lainnya.

Endang (dalam Khobir, 2009) juga menyatakan selama ini pola permainan modern cenderung seperti kebanyakan pola pendidikan formal anak yang mengharuskan mereka duduk terkurung dalam kamar berjam-jam, sehingga pola permainan ini dapat membahayakan mental anak, selain anak hanya terbiasa dengan egonya sendiri, anak-anak terdorong untuk menjadi individu anti sosial.

Lebih jauh Purnomo (dalam Nur, 2013) ada berbagai dampak yang timbul akibat penggunaan game online pada anak seperti perilaku agresif baik itu secara verbal maupun fisik. Permainan modern ini lebih banyak dimainkan secara statis, anak bermain dalam keadaan pasif. Mereka duduk dan diam yang bekerja hanya jemarinya saja. Hal ini menyebabkan anak tidak peduli pada lingkungan sekitar yang akan mempengaruhi interaksi sosial anak, akibatnya anak akan jadi pemalu, penyendiri, dan individualistis (Misbach \& Cahyono dalam Nur, 2013).

Bangsa Indonesia adalah bangsa yang sangat kaya dalam segala bidang begitu juga dengan jenis permainan tradisional yang bisa digunakan demi menjaga pola perkembangan anak bangsa, sehingga dapat terhidar dari dampak-dampak negative permainan modern. Selain itu permainan tradisional telah terbukti dapat menimbulkan karakter positif pada anak (Nur, 2013). Karakter permainan tradisional yang dapat membentuk karakter positif pada anak menurut Cahyo (dalam Nur, 2013) yaitu: (A)permainan tradisional cenderung menggunakan alat atau fasilitas yang tersedia dilingkungan tanpa harus 
membelinya sehingga perlu daya imajinasi dan kreativitas yang tinggi. Banyak alat-alat permainan yang dibuat atau digunakan dari tumbuhan, tanah, genting, batu atau pasir. Misalkan mobil-mobilan yang terbuat dari kulit jeruk bali, engrang yang terbuat dari bambu, dan lain sebagainya. permainan anak tradisional melibatkan pemain yang relatif banyak. Tidak mengherankan kalua kita lihat hampir setiap permain rakyat begitu banyak anggotanya, sebab selain mendahulukan faktor kesenangan bersama, permainan ini juga mempunyai maksud lebih pada pendalaman kemampuan interaksi antar pemain (potensi interpersonal), seperti cak bur, petak umpet, congklak, gerobak sodor dan lain-lain. (C) Permainan tradisional meiliki nilai-nilai luhur dan pesan-pesan moral tertentu seperti nilai kebersamaan, kejujuran, tanggung jawab, sikap lapang dada ketika kalah, dorongan berprestasi dan taat pada aturan.

Lebih jauh Misbach (2006) menyampaikan bahwa dalam permainan tradisional dapat menstimulasi berbagai aspek perkembangan anak yang meliputi hal-hal sebagai berikut: aspek motorik, sosial, kognitif, emosi, bahasa, spiritual, moral dan aspek ekologis.

Permainan cak bur atau permainan galah panjang adalah jenis permainan tradisional yang sering dimainkan oleh anak-anak di Sumatera Barat dan Riau. Permainan ini dilakukan oleh 2 tim yang dimana setiap tim terdiri atas beberapa orang. Salah satu tim bertugas untuk penjaga galah dan satu tim berperan sebagai penerobos. Permainan tradisional yang dilakukan dengan jumlah yang banyak dengan kata lain dilakukan secara berkelompok menurut Cahyo (dalam Nur, 2013) mampu menumbuhkan karakter positif bagi anak yang ditandai dengan munculnya interaksi sosial diantara pemain. Menurut Gilin dan Gilin (dalam, Soekanto, 2001) interaksi sosial merupakan hubungan dinamis yang menyangkut hubungan antara orang perorang, antara kelompok dengan kelompok maupun orang perorang dengan kelompok.

Berdasarkan hasil pengamatan dan wawancara yang peneliti lakukan di beberapa taman kanak-kanak di kota Padang terdapat 13 orang yang mengalami kesulitan dalam melakukan interaksi sosial sehingga belum mampu membangun hubungan yang dinamis, yang terlihat dari komunikasi yang kurang efektif antar siswa, cenderung bermain sendiri, menyukai game yang berbentuk digital, suka menonton televisi hingga larut malam hingga tertidur didalam kelas, pendiam, masih harus arahakan oleh guru untuk bermain secara kelompok, memiliki rasa kepemilikan yang tinggi sehingga tidak mau berbagi mainan dengan teman, bahkan salah satu siswa akan menyakiti dirinya sendiri ketika apa yang dia kehendaki tidak bisa diperolehnya sehingga susah untuk bergabung dalam kelompok bermain.

Berdasarkan penjelasan diatas maka, peneliti tertarik untuk melakukan penelitian tentang efektifitas permainan tradisional cak bur terhadap peningkatan interaksi sosial siswa taman kanak-kanak. 


\section{METODE PENELITIAN}

Studi ini menggunakan metode penelitian eksperimen dengan desain penelitian pretest postest group control. Subjek dalam penelitian ini adalah 37 orang siswa taman kanak-kanak. Pemilihan subjek dilakukan dengan teknik simple random sampling metode pemilihan sampel dengan cara menarik $\mathrm{n}$ dari sebuah populasi tertentu yang besarnya $\mathrm{N}$, sehingga tiap unit sampel mempunyai peluang yang sama untuk dipilih (Nazir, 1999). Subjek dibagi kedalam dua kelompok yaitu kelompok kontrol dan kelompok eksperimen. Kelompok eksperimen inilah yang mendapatkan intervensi berupa permainan cak-bur, sedangkan kelompok control tidak diberikan perlakuan apapun dibiarkan dalam kondisi alami.

Penelitian dilaksanakan kurang lebih selama 10 hari dimana diawali dengan pengambilan data pretest dan diakhiri posttest setelah intervensi diberikan. Dalam intervensi ini para peneliti hanya bertugas sebagai fasilitator sedangkan para anggota kelompok eksperimen diberikan kesempatan untuk bermain cak-bur.

Variabel dalam penelitian ini adalah 1) Permainan cak bur adalah sebuah permainan tradisional yang terdiri atas dua tim, dimana satu tim bertindak sebagai penjaga gelanggang yang meneriaki kata cak, tanda pertandingan dimulai, dan bertugas untuk menjaga gelanggang agar tim lawan tidak bisa melewatinya, setiap orang dalam tim ini menjaga satu garis yang menjadi tanggung jawabnya dan dia tidak boleh keluar dari garis yang dia jaga, sedangkan tim lain bertugas untuk melewati penjaga untuk dapat kembali kedepan jika sudah sampai semua anggota kedepan mereka harus berteriak bur tanda permaian berakhir. Permainan ini akan diberikan sebagai bentuk intervensi atau perlakuan kepada subjek penelitian. 2) Interaksi sosial adalah hubungan individu dengan individu, individu dengan kelompok, dan kelompok dengan kelompok, dimana perilaku individu yang satu mempengaruhi, mengubah atau memperbaiki perilaku individu yang lain atau sebaliknya sehingga tercipta hubungan yang dinamis. Pengukuran interaksi sosial dilakukan dengan menggunakan skala interaksi sosial berdasarkan teori Soekanto (2001) yang dirancang dengan menggunakan skala sikap likert.

Pengolahan data dilakukan secara kuantitatif dengan uji t-test untuk melihat perbedaan mean kelompok kontrol dan kelompok eksperimen. Peneliti juga menggunakan metode Effect size untuk melihat seberapa efektifkan permainan tradisional cak bur untuk meningkatkan interaksi siswa taman kanak-kanak di kota Padang.

\section{HASIL DAN PEMBAHASAN}

Berdasarkan hasil uji t-test didapatkan hasil sebesar $\mathrm{t}=19,985$ dengan taraf signifikansi 0,000 . Hal ini menunjukan ada perbedaan yang signifikan dalam peningkatan interaksi sosial antara siswa taman kanak-kanak yang mengikuti permainan tradisional cak bur (kelompok eksperimen) dengan 
siswa taman kanak-kanak yang tidak mengikuti permainan tradisional cak bur (kelompok kontrol). Sedangkan untuk melihat seberapa efektif permainan tradisional cak bur dalam meningkatkan interaksi sosial pada siswa taman kanak-kanak digunakan teknik Effect Size.

Salah satu teknik Effect size yang sering digunakan pada penelitian eksperimental adalah Cohen's d. Cohen's d merupakan teknik yang mengukur perbedaan antara mean untuk tingkatan variabel independen dibagi dengan deviasi standar pada kelompok (Shaughnessy, dkk, 2012). Berdasarkan rumus dari cohen's tersebut didapatkan nilai effect size sebesar 7,77 hal ini berarti permainan tradisional cak bur efektif untuk meningkatkan interaksi sosial pada siswa taman kanak-kanak di kota Padang.

Berdasarkan uji statitik diatas dapat disimpulkan bahwa hipotesis kerja (Ha) permainan tradisional cak bur efektif untuk meningkatkan interakasi sosial pada siswa taman kanak-kanak.

\section{PEMBAHASAN}

Efektifnya permainan tradisonal cak bur ini untuk meningkatkan kemampuan interaksi sosial pada anak karena pada dasarnya permainan tradisional ini melibatkan pemain yang relatif banyak sehingga untuk terlibat dalam permainan ini membutuhkan kerjasama dan permainan ini tidak mencari kesenangan semata tetapi lebih bermaksud pada pendalaman interaksi antar pemain, selain itu sebagian besar permainan tradisional memiliki nilai- nilai luhur dan pesan-pesan moral tertentu seperti nilai kebersamaan, kejujuran, tanggung jawab, sikap lapang dada dan taat pada aturan (Cahyo dalam Nur, 2013).

Hasil penelitian dilakukan oleh Kurniati (2011) juga menunjukan bahwa permainan anak tradisional dapat menstimulasi anak dalam mengembangkan kerjasama, membantu anak menyesuaikan diri, saling berinteraksi secara positif, dapat mengkondisikan anak dalam mengontrol diri, mengembangkan sikap empati terhadap teman, menaati aturan serta menghargai orang lain. Hal ini diperkuat oleh penelitian yang dilakukan oleh Susanti dkk (2010) dimana Susanti dkk mengatakan bahwa peningkatan kompetensi interpersonal anak dapat dilakukan melalui permainan tradisional (Jurnal Psikologi Undip Vol.8, No.2). Hasil penelitian yang kurang lebih sama juga disampaikan oleh Rini (Susanti dkk, 2010) yang membuktikan bahwa permainan tradisional dapat mempengaruhi kematangan sosial pada anak sekolah dasar.

Hal yang kurang lebih sama juga disampaikan oleh Misbach (2006) bahwa permainan tradisional memiliki peran dalam menstimulasi perkembangan anak, seperti: (a) Melatih aspek motorik: daya tahan, daya lentur, sensormotorik, motorik kasar dan motorik halus. (b) Melatih aspek kognitif: mengembangkan imajinasi, kreativitas, problem solving, strategi, antisipatif, pemahaman kontekstual. (c) Melatih aspek bahasa: pemahaman konsep-konsep nilai. (d) aspek spiritual: 
menyadari keterhubungan dengan sesuatu yang bersifat agung. (e) Melatih aspek ekologis: memahami pemamfaatan elemen-elemen alam sekitar secara bijaksana (f) Melatih aspek emosi: mengasah empati, pengendalian diri dan katarsis emosional. (g) Melatih aspek nilai moral: menghayati nilai moral yang diwariskan dari generasi terdahulu kegenerasi selanjutnya. (h) melatih aspek sosial: melalui permainan tradisional ini anak-anak mampu mengembangkan kemampuan menjalin relasi, kerjasama, melatih kematangan sosial dengan teman sebaya dan meletakan pondasi untuk melatih keterampilan sosialisasi berlatih peran dengan orang yang lebih dewasa atau masyarakat.

\section{SIMPULAN}

Berdasarkan hasil dan pembahasan diatas dapat ditarik kesimpulan bahwa permainan tradisional cak bur efektif untuk meningkatkan kemampuan interaksi sosial pada siswa taman kanak-kanak.

Kesimpulan ini didapatkan setelah melalui suatu proses, yakni proses analisis data, yang terdiri atas pengujian beberapa asumsi, yakni uji normalitas data dan uji homogenitas serta pengujian hipotesis. Pengujian hipotesis dilakukan dengan menggunakan teknik analisis data $T$ Test dengan bantuan program SPSS for Windows 16, yakni Independent Sampels T-Test. Dari proses analisa data tersebut, dapat ditarik kesimpulan bahwa Hipotesis Nihil (Ho) ditolak dan
Hipotesis Kerja (Ha) yang berbunyi "Permainan tradisional cak bur efektif untuk meningkatkan kemampuan interaksi sosial pada siswa taman kanak-kanak" diterima.

\section{SARAN}

Berdasarkan kesimpulan yang dipaparkan sebelumnya, maka dapat disarankan beberapa hal, yaitu: 1) Saran bagi pihak sekolah diharapkan untuk dapat menyajikan permainan tradisional cak bur sebagai salah satu program disekolah sehingga interaksi sosial siswa mengalami peningkatan. 2) Orang tua hendaknya mendukung anak secara bijaksana dalam bermain karena bermain merupakan dunia anak. Orang tua tidak hanya terlibat dalam fungsi mengawasi, tetapi juga berfungsi untuk mendorong anak bermain permainan yang memiliki unsur-unsur edukatif terutama permainan-permainan tradisional. 3) Pemerintah hendaknya mendorong masyarakat dan guru-guru untuk mengembangkan permainanpermaian tradisional yang memiliki dampak positif pada anak sehingga permainan ini tidak punah seiring perkembangan zaman. 4) Bagi peneliti selanjutnya yang berminat dengan penelitian sejenis dapat menggunakan permain tradisional lain yang banyak berkembang di masyarakat.

\section{DAFTAR PUSTAKA}

Khobir, Abdul. 2009. Upaya Mendidik Anak Melalui Permainan Edukatif. Forum Tarbiyah Vol 7 No. 2. (http://ejournal .stain- 
pekalongan.ac.id/index.php/Forta/ article/download/262/233)

Kurniati, Euis. 2011. Program Bimbingan Untuk Mengembangkan Keterampilan Sosial Anak Melalui Permainan Tradisional. Surakarta. Jurnal (tidak diterbitkan): UMS.

Latif, Mukhtar dkk. 2013. Orientasi Baru Pendidikan Anak Usia Dini (Teori dan Aplikasi). Jakarta: Kencana Prenada Media Group.

Misbach, Ifa H. 2006. Peran Permainan Tradisional Yang Bermuatan Edukatif Dalam Menyumbang Pembentukan Karakter Bangsa. Bandung Laporan Penelitian (tidak diterbitkan): Universitas Pendidikan Indonesia.

Nur, Haerani. 2013. Membangun Karakter Anak Melalui Permainan Anak Tradisional. Journal Pendidikan Karakter No 1, Tahun III, Februari 2013.

Retno, Soendari dan Wismiarti. 2010 Sentra Persiapan. Jakarta: Pustaka Al-Falah.

Sari. 2011. Analisis Permaian Tradisonal: Permainan Cak Bur Dari Minang. (http://zayulisman.blogspot.com)

Shaughnessy, Jhon J dkk. 2012. Metode Penelitian Dalam Psikologi. Jakarta: Salemba Humanika.

Soekanto, Soejono. 2001. Sosiologi Suatu Pengantar. Jakarta: Raja Grafindo Persada.
Susanti, Fitria dkk. 2010. Pengaruh Permainan Tradisional Terhadap Kompetensi Interpersonal Dengan Teman Sebaya Pada Siswa SD. Jurnal Psikologi Undip Vol. 8, No2, Oktober 2010.

Wahyuni, I.S. 2009. Efektivitas Pemberian Permainan Tradisional Grobak Sodor Terhadap Penyesuaian Sosial Anak Sekolah Dasar Negeri Cakraningrat Surakarta. Ringkasan Skripsi (tidak diterbitkan): UMS. 